\title{
FAST AND FRUGAL TREES IN THE WILD
}

\author{
Laura Martignon \\ Ludwigsburg University of Education, Ludwigsburg, Germany \\ martignon@ph-ludwigsburg.de
}

A list of fast and frugal trees successfully used in different fields of application are described, presented and illustrated. Fast-and-frugal trees can be used as decision-making tools which operate as lexicographic classifiers, and, if required, associate an action (decision) to each class or category. They were introduced and conceptualized in 2003 (Martignon, et al, 2003; Martignon, Katsikopoulos and Woike, 2008) and are now systematically used in a variety of applied fields. Here a list of such trees used in specific domains is presented and illustrated with corresponding diagrams.

\section{REFERENCES}

Martignon, L., Katsikopoulos, K. V., \& Woike, J. K. (2008). Categorization with limited resources. A family of simple heuristics. Journal of Mathematical Psychology, 52, 352-361.

Martignon, L., Vitouch, O., Takezawa, M., \& Forster, M. (2003). Naïve and yet enlightened: From natural frequencies to fast and frugal decision trees. In D. Hardman, \& L. Macchi (Eds.), Thinking: Psychological perspectives on reasoning, judgment, and decision making (pp. 189211). Chichester, United Kingdom: John Wiley and Sons. 